\title{
Rezygnacja ze zwolnienia od podatku VAT dostawy lokalu mieszkalnego przez dewelopera
}

\author{
Resignation from the VAT exemption of sales \\ of residential premises by the developer
}

Streszczenie. Instytucje podatkowe powinny być tworzone w sposób racjonalny, tak aby nadmiernie nie ograniczać obrotu gospodarczego. Uregulowania dotyczące możliwości rezygnacji ze zwolnienia dostawy lokalu mieszkalnego od podatku VAT charakteryzują się wysokim poziomem formalizmu, wpływając negatywnie na proces dokonywania sprzedaży przez dewelopera. Niniejsze opracowanie poświęcone jest fragmentowi przepisów Ustawy o VAT dotyczącemu rezygnacji ze zwolnienia z opodatkowania podatkiem od towarów i usług dostawy lokalu mieszkalnego, co wymaga w pewnym zakresie odwołania się do regulacji tej Ustawy dotyczącej samych zwolnień. Celem artykułu jest zbadanie prawidłowości transpozycji Dyrektywy 112 do polskiego porządku prawnego w zakresie zwolnień nieruchomości z podatku VAT, przesłanek umożliwiających skorzystanie ze zwolnienia fakultatywnego, oraz możliwości skorzystania z rezygnacji z tego zwolnienia przez podatnika.

Słowa kluczowe: podatek od towarów i usług; VAT; zwolnienia podatkowe; wybór opodatkowania; prawo podatkowe UE. 


\begin{abstract}
Tax institutions should be construed in a rational manner, in order so as to not restrict economic turnover excessively. The regulations concerning the possibility to resign from the VAT exemption of sales of residential premises by the developer characterizes by the high level of formalism which affects in a negative manner the sales process performed by the developer. This paper is devoted to the fragment of the polish Act on the goods and services tax governing the issue of resignation from the VAT exemption of sales of residential premises, which implies in a certain extent to appeal to the regulation of exemptions stipulated in this Act. The subject matter of this analysis is to examine the correctness of transposition of the Directive 112 into polish legal system in the field of real estate exemptions from VAT, the conditions for exercising the optional exemption, as well as the benefit of the resignation from the VAT exemption by the taxpayer.
\end{abstract}

Keywords: tax on goods and services; VAT; tax exemptions; resignation from the VAT exemption; choice of taxation; EU tax regulations.

\title{
1. Uwagi wstępne
}

Wejście w życie 29 kwietnia 2012 roku przepisów Ustawy o ochronie praw nabywcy lokalu mieszkalnego lub domu jednorodzinnego ${ }^{1}$, potocznie zwanej ustawą deweloperską, skutkowało powstaniem po stronie deweloperów szeregu nowych obowiązków dotyczących zarówno procesu realizacji inwestycji mieszkaniowej, jak i samego zbywania lokalu mieszkalnego. Chcąc chociaż częściowo uchylić się od powinności wprowadzonych nową regulacją, a także dążąc do podatkowo-prawnej optymalizacji prowadzonej działalności gospodarczej, praktyką deweloperów mieszkaniowych stało się tworzenie spółek celowych już nie tylko na potrzeby realizacji konkretnej inwestycji (planowanie, budowa, sprzedaż), ale również dla samego etapu sprzedaży nieruchomości lokalowych już po ich wybudowaniu. Transakcja dostawy nieruchomości lokalowej pomiędzy podmiotami prowadzącymi działalność gospodarczą (spółki

1 Ustawa z dnia 16 września 2011 r. o ochronie praw nabywcy lokalu mieszkalnego lub domu jednorodzinnego (tekst jedn.: Dz.U. z 2016 poz. 555 ze zm., dalej: ustawa deweloperska). 
celowe) na tzw. rynku pierwotnym, co do zasady, opodatkowana będzie podatkiem od towarów i usług w odpowiednio obowiązującej stawce ${ }^{2}$. Obowiązek podatkowy w podatku VAT rozciągać się będzie również na kolejną sprzedaż takiego lokalu, ale tylko do końca upływu okresu dwóch lat od jego pierwszego zasiedlenia. Ze względu na prawo do odliczenia VAT naliczonego w interesie dewelopera jest, aby sprzedaż lokalu mieszkalnego również po upływie tego dwuletniego okresu opodatkowana została podatkiem od towarów i usług w miejsce podatku od czynności cywilnoprawnych. Taką możliwość dają deweloperowi przepisy art. 43 ust 10 ustawy o $\mathrm{VAT}^{3}$ określające warunki i sposób rezygnacji ze zwolnienia z podatku od towarów i usług opisanego w art. 43 ust. 1 pkt. 10 tej samej ustawy.

Przedmiotem niniejszego opracowania jest analiza regulacji rezygnacji ze zwolnienia z opodatkowania podatkiem VAT z art. 43 ust. 10 ustawy o VAT w zw. art. 43 ust. 1 pkt. 10 tej Ustawy, w kontekście możliwości i warunków skorzystania z tej instytucji przez dewelopera mieszkaniowego. Regulacja ta charakteryzuje się wysokim poziomem formalizmu, co ograniczać może swobodę obrotu na rynku nieruchomości mieszkaniowych, ponad ograniczenia wynikające przede wszystkim z przepisów prawa cywilnego. Ponadto, w świetle najnowszego orzecznictwa sądów administracyjnych wątpliwości może budzić sam sposób ukształtowania instytucji zwolnienia z podatku VAT dostawy nieruchomości, a w konsekwencji rezygnacji z tego zwolnienia, wynikający z możliwości wadliwego transponowania przepisów Dyrektywy 112 w sprawie wspólnego systemu podatku od wartości dodanej ${ }^{4}$ do polskiego porządku prawnego.

\footnotetext{
2 Szerzej na ten temat: K. Kopyściańska, Przeglq̨d bieżq̨cych problemów zwiqzzanych z opodatkowaniem nieruchomości na tle orzecznictwa sq̨ów administracyjnych, Wrocław 2015, s. 230-236.

3 Ustawa z dnia 11 marca 2004 r. o podatku od towarów i usług (tekst jedn. Dz.U. z 2016 r., poz. 710 ze zm., dalej: ustawa o VAT).

4 Dyrektywa 2006/112/ WE Rady z dnia 28 listopada 2006 r. w sprawie wspólnego systemu podatku od wartości dodanej (Dz.Urz. UE L 2006, nr 347 z dnia 11 grudnia 2006 r., s. 1, dalej: Dyrektywa 112).
} 
Podstawowym problemem badawczym opracowania jest odpowiedź na pytanie, czy poziom formalizmu, jakim charakteryzuje się instytucja rezygnacji ze zwolnienia z opodatkowania podatkiem VAT dostawy lokalu mieszkalnego, jest uzasadniony fiskalnymi celami opodatkowania, czy też jest to formalizm nadmierny, który działa hamującą na obrót pomiędzy deweloperem, rozumianym jako spółka celowa realizująca sprzedaż, a nabywcą lokalu. Konieczne zatem staje się udzielenie odpowiedzi na pytania szczegółowe, tj.: czy transpozycja przepisów prawa unijnego w zakresie zwolnienia z podatku VAT dostawy nieruchomości została dokonana w sposób uwzględniający intencje ustawodawcy unijnego; czy konstrukcja przepisów dotyczących zwolnienia w tym zakresie, a także rezygnacji z tego zwolnienia, jest wystarczająco jasna i precyzyjna, nie tworząc dodatkowego pola do interpretacji, a także czy istnieje możliwość ograniczenia wymogów formalnych związanych z rezygnacją przez strony z opodatkowania transakcji podatkiem VAT po upływie dwóch lat od pierwszego zasiedlenia nieruchomości, przy zachowaniu stricte fiskalnych celów prawa podatkowego. Celem odpowiedzi na te pytania uzasadnione jest przeprowadzenie analizy instytucji tzw. fakultatywnego zwolnienia dostawy nieruchomości z podatku VAT, a w konsekwencji instytucji rezygnacji z tego zwolnienia, na płaszczyźnie prawa zarówno polskiego, jak i unijnego.

\section{Lokal mieszkalny jako część budynku podlegająca zwolnieniu}

Ustawodawca w artykule 43 ust. 10 ustawy o VAT wskazuje na możliwość, po spełnieniu określonych warunków, rezygnacji przez strony transakcji ze zwolnienia od podatku VAT dostawy budynków, budowli lub ich części. Ustawa o VAT czy też przepisy ogólnego prawa podatkowego nie definiują pojęcia budynku, budowli lub części tych nieruchomości. Przepisy te nie wyjaśniają również pojęcia lokalu mieszkalnego, a zatem nie dokonują kwalifikacji lokalu mieszkalnego jako elementu 
części pojęcia budynku ${ }^{5}$. Wskazówkę w zakresie rozumienia pojęcia budynku w ramach prawa podatkowego mogłyby stanowić przepisy ustawy o podatkach i opłatach lokalnych ${ }^{6}$, a także przepisy zewnętrznych wobec prawa podatkowego gałęzi prawa. Ustawa o VAT nie wprowadza jednak odwołań do tego rodzaju aktów prawnych. W prawie podatkowym punktem wyjścia do przeprowadzenia procesu interpretacji przepisu powinna być wykładnia językowa danego pojęcia ${ }^{7}$. Wyniki tej wykładni nie mogą jednak prowadzić do przyznawania pierwszeństwa potocznemu znaczeniu danego pojęcia ponad znaczeniem ugruntowanym w prawie, choćby dotyczyło to innych jego dziedzin czy nawet gałęzi prawa ${ }^{8}$. Stąd konieczność sięgnięcia do wykładni celowościowej, a nawet systemowej ${ }^{9}$. Wydaje się zatem, że pojęcie budynku i jego części na gruncie ustawy o VAT powinno być interpretowane $\mathrm{z}$ uwzględnieniem miejsca tych pojęć w ustawach podatkowych, ale przede wszystkim w prawie w ogóle, jednak tak, aby nie pozostawać w opozycji do potocznego rozumienia tych słów. Jak wskazał NSA w wyroku z dnia 11 czerwca 1997 r., dokonując interpretacji pojęcia niezdefiniowanego w ustawie podatkowej, a którego definicja znajduje się w przepisach prawa budowlanego, „należy się posługiwać przede wszystkim potocznym rozumieniem tych pojęć, definicjami encyklopedycznymi, a pomocniczo również rozwiązaniami przyjętymi w prawie budowlanym” ${ }^{\text {. }}$ Zgodnie z art. 146 Rozporządzenia Pre-

5 J. Koziollek, Najem komercyjny lokali mieszkalnych a zwolnienie z podatku VAT, „Studenckie Prace Prawnicze, Administratywistyczne i Ekonomiczne” 2015, nr 17, s. 104.

6 Ustawa z dnia 12 stycznia 1991 r. o podatkach i opłatach lokalnych (tekst jedn.: Dz.U. z 2016 poz. 716 ze zm., dalej: u.p.o.l).

R. Wolański, System podatkowy w Polsce, Warszawa 2016, s. 67.

8 W. Nykiel, Wykładnia prawa podatkowego wewnętrznego, międzynarodowego, i prawa podatkowego Unii Europejskiej (wybrane zagadnienia), „Kwartalnik Prawa Podatkowego" 2004, nr 4, s. 132.

9 C. Kosikowski, E. Ruśkowski, A. Borodo, Finanse publiczne i prawo finansowe, Oficyna a Wolters Kluwer business, Warszawa 2008, s. 83, jak wskazuje Naczelny Sąd Administracyjny $\mathrm{w}$ orzeczeniu $\mathrm{z}$ dnia 6 listopada 2003 r. „Jedynym kryterium w zakresie wyboru metody wykładni powinna być poprawność efektów tej wykładni, a nie dogmatyczne założenie swoistej «wyższości» jednego rodzaju wykładni nad innymi”; Wyrok NSA z dnia 6 listopada 2003 r., III RN 133/02, OSNAPU 200415 poz. 254.

10 Wyrok NSA w Gdańsku z dnia 11 czerwca 1997 r., I SA/Gd 151/97, LEX nr 306001. 
zesa Rady Ministrów w sprawie „Zasad techniki prawodawczej”11 w ustawie formułuje się definicję danego określenia, jeżeli dane określenie jest wieloznaczne; jest nieostre, a pożądane jest ograniczenie jego nieostrości; znaczenie danego określenia nie jest powszechnie zrozumiałe; ze względu na dziedzinę regulowanych spraw istnieje potrzeba ustalenia nowego znaczenia danego określenia. Mając na uwadze, że prawo budowlane stanowi podstawowy akt prawny regulujący status nieruchomości budynkowych, pojawia się pytanie o celowość konstruowania autonomicznej definicji budynku na gruncie ustawy o VAT, czy też o sens powielania definicji zawartych $\mathrm{w}$ prawie budowlanym $\mathrm{w}$ ustawach podatkowych $^{12}$.

Zgodnie z treścią artykułu 1a ust. 1 pkt. 1 u.p.o.l. budynkiem jest obiekt budowlany w rozumieniu przepisów prawa budowlanego, który jest trwale związany z gruntem, wydzielony z przestrzeni za pomocą przegród budowlanych oraz posiada fundamenty i dach. Definicja ta jest identyczna, jak ta zawarta w Ustawie prawo budowlane ${ }^{13}$. Definicja ta również wydaje się nie być sprzeczna ze słownikowym, tj. potocznym rozumieniem pojęcia budynku, jako 'naziemnej budowli mającej dach i ściany ${ }^{, 14}$. Takie rozumienie budynku na gruncie ustawy o VAT należałoby uznać zatem za odpowiadające celom tej regulacji.

O ile potwierdzenia znaczenia pojęcia budynku można doszukiwać się w innych ustawach podatkowych czy gałęziach prawa, o tyle pojęcie części budynku wydaje się mieć charakter bardziej intuicyjny, potoczny. Według słownika języka polskiego część, to ‘jeden z elementów, na które dzieli się jakaś całość, pewna ilość z całości', względnie 'przedmiot stanowiący jakiś dający się samodzielnie wyodrębnić element większej ca-

11 Rozporządzenie Prezesa Rady Ministrów z dnia 20 czerwca 2002 r. (tekst. jedn. Dz.U. z 2016 r., poz. 283 ze zm.).

12 Więcej o możliwości zastosowania w prawie podatkowym definicji zawartych w innych gałęziach prawa: P. Borszowski, Działalność gospodarcza w konstrukcji prawnej podatku, Warszawa 2010, s. 27-30, jak również E. Bobrus, Opodatkowanie przeniesienia własności nieruchomości, Warszawa 2012, s. 41-44.

13 Ustawa z dnia 7 lipca 1994 r. Prawo budowlane (tekst jedn. Dz.U. z 2016 r., poz. 290, ze zm.), dalej: pr. bud.

14 M. Bańko (red.), Słownik języka polskiego, Tom I, Warszawa 2007, s. 168. 
łości ${ }^{15}$. Wychodząc od takiej słownikowej definicji, Samorządowe Kolegium Odwoławcze w Bydgoszczy określa, na potrzeby podatku od nieruchomości, że „częścią budynku może być jakiś jego ułamek bądź okre-

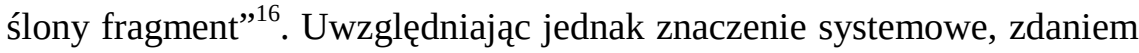
SKO, część budynku musi spełniać elementy definicji właściwe dla budynku, tj. być trwale związana z gruntem, wydzielona z przestrzeni za pomocą przegród budowlanych oraz posiadać fundamenty i dach. Potwierdza to Wyrok WSA w Gliwicach, zgodnie z którym, aby część budynku stanowiła odrębny przedmiot opodatkowania, musi charakteryzować się warunkom właściwym dla nieruchomości budynkowej ${ }^{17}$. W orzeczeniu tym Wojewódzki Sąd Administracyjny ponadto bezpośrednio wymienia, jakie elementy budynku należy uznać za jego części. Według WSA, w rozumieniu ustawy podatkowej takimi częściami budynku będą „poszczególne elementy budynku, lokal czy lokale, stanowiące całość techniczno-użytkową wyodrębnione, jak i niewyodrębnione w znaczeniu prawa cywilnego”. W świetle tych rozważań należy uznać, że art. 43 ust. 10 ustawy o VAT w tym zakresie, w jakim dotyczy części budynku, będzie dotyczył lokali, w tym tych o charakterze mieszkalnym.

\section{Podstawa zwolnienia z podatku VAT a możliwość rezygnacji ze zwolnienia}

Artykuł 43 ust. 1 ustawy o VAT wprowadza kategorię tzw. zwolnień przedmiotowych od podatku VAT. Zwolnienia te dotyczyć będą jedynie tych czynności, które podlegają opodatkowaniu na podstawie art. 5 tej samej ustawy ${ }^{18}$. Ustawa przewiduje dwa rodzaje zwolnień dostawy części budynku, jaką zgodnie z poprzednio poczynionymi ustaleniami, stanowić

15 Tamże.

16 Decyzja Samorządowego Kolegium Odwoławczego w Bydgoszczy z dnia 9 września 2005 r., SKO-4231/87/2005, LEX nr 1725946.

17 Wyrok WSA w Gliwicach z dnia 2 grudnia 2009 r., I SA/Gl 563/2009, LEX nr 582592.

18 A. Piątkowska-Chmiel, Komentarz do art. 43 Ustawy o podatku od towarów i usług, [w:] J. Matarewicz (red.), Ustawa o podatku od towarów i usług. Komentarz, Warszawa 2013, s. 425. 
będzie lokal mieszkalny. Są to tzw. zwolnienie generalne z art. 43 ust. 1 pkt. 10 Ustawy o VAT oraz zwolnienie nieobjęte generalnym zwolnieniem z art. 43 ust. 1 pkt 10, o którym mowa w ust. 1 pkt. 10a tego samego artykułu. Zgodnie z pkt. 10 zwolnieniu podlegać będzie każda dostawa budynków, budowli lub ich części, za wyjątkiem dwóch sytuacji, tj. gdy dostawa jest dokonywana w ramach pierwszego zasiedlenia lub przed nim oraz gdy pomiędzy pierwszym zasiedleniem a dostawą budynku, budowli lub ich części upłynął okres krótszy niż 2 lata. W przypadku, gdyby na podstawie art. 43 ust. 1 pkt. 10 zwolnienie nie było możliwe, zgodnie z pkt. 10a dostawa może zostać zwolniona pod warunkiem, że: a) w stosunku do obiektów podlegających dostawie nie przysługiwało dokonującemu ich dostawy prawo do obniżenia kwoty podatku należnego o kwotę podatku naliczonego, b) dokonujący dostawy tych obiektów nie ponosił wydatków na ich ulepszenie, w stosunku do których miał prawo do obniżenia kwoty podatku należnego o kwotę podatku naliczonego, a jeżeli ponosił takie wydatki, to były one niższe niż 30\% wartości początkowej tych obiektów.

Zastosowanie regulacji z pkt. 10 bądź 10a artykułu 43 ust. 1 ustawy o VAT wywoływać będzie identyczne skutki na gruncie prawa podatkowego, tj. zwolnienie z opodatkowania nieruchomości podatkiem od towarów i usług. Zróżnicowanie tych instytucji wynika z zakresu możliwości udzielonych podatnikowi przez ustawodawcę celem wyboru dogodnej dla podatnika formy opodatkowania ${ }^{19}$. Zwolnienie z artykułu 43 ust. 1 pkt. 10 charakteryzuje się pewnym poziomem fakultatywności. Oznacza to, że przy zaistnieniu określonego stanu faktycznego, z mocy prawa, dostawa nieruchomości objęta zostanie zwolnieniem. Podatnik jednak, po spełnieniu określonych wymogów, o których mowa art. 43 ust. 10 i 11 ustawy o VAT, może z tego zwolnienia zrezygnować i wybrać opodatkowanie dostawy podatkiem VAT. Punkt 10a ustępu 1 tego samego artykułu stanowi natomiast o tzw. zwolnieniu obligatoryjnym, tj. takim, które będzie mieć zastosowanie $\mathrm{w}$ danym stanie faktycznym niezależnie od woli podatnika. Rozstrzygając kwestię sposobu opodatkowania dostawy

19 Więcej: G. Kaptur, Zwolnienie dostawy budynków/budowli w podatku VAT, cz. I, „Nieruchomości” 2011, nr 8, s. 21. 
lokalu mieszkalnego, deweloper zobligowany jest zatem do dokonania skomplikowanej analizy, czy dana transakcja dostawy spełnia przesłanki skutkujące zwolnieniem (art. 43 ust. 1 pkt. 10 ustawy o VAT) z możliwością rezygnacji z tego zwolnienia, czy też na podstawie art. 43 ust. 1 pkt. 10a zwolnienie będzie mieć charakter obligatoryjny. W przypadku dokonania błędnej kwalifikacji, podmiot prowadzący działalności gospodarczą mającą za przedmiot lokal mieszkalny ryzykuje negatywnymi konsekwencjami podatkowymi wynikającymi przede wszystkim z niewłaściwej kalkulacji ceny sprzedaży.

\section{Pierwsze zasiedlenie nieruchomości jako centralne pojęcie regulacji ustawy o VAT dotyczącej zwolnień}

W artykule 43 ust. 1 pkt. 10 ustawy VAT ustawodawca wskazał okres, w którym dostawa nieruchomości nie będzie korzystać z generalnego zwolnienia z podatku VAT. Opodatkowana podatkiem VAT będzie zatem dostawa lokalu mieszkalnego (jako części budynku) dokonywana w ramach pierwszego zasiedlenia lub przed nim (podpunkt a), ale również, gdy pomiędzy pierwszym zasiedleniem a dostawą upłynął okres nie krótszy niż 2 lata (podpunkt b). Treść artykułu 43 ust. 1 pkt. 10 ustawy o VAT wskazuje, że jednym z centralnych pojęć instytucji zwolnienia nieruchomości z podatku VAT jest pojęcie pierwszego zasiedlenia nieruchomości.

Pojęcie pierwszego zasiedlenia nie jest pojęciem nowym na gruncie ustawy o VAT. Już w pierwotnym tekście ustawy ${ }^{20} \mathrm{w}$ słowniczku zawartym w art. 2 pkt. 14 ustawodawca wprowadził definicję tego pojęcia. Zgodnie z pierwotnym brzmieniem tekstu ustawy o VAT przez pierwsze zasiedlenie należało rozumieć wydanie pierwszemu nabywcy lub pierwszemu użytkownikowi obiektów budownictwa mieszkaniowego lub ich części w wykonaniu czynności podlegających opodatkowaniu. Definicja ta była kompatybilna z ówczesną regulacją dotyczącą zwolnień nieru-

20 Ustawa z dnia 11 marca 2004 r. o podatku od towarów i usług (Dz.U. Nr 54 poz. 535). 
chomości z podatku od towarów i usług, która określała, że zwolnieniem objęta jest tylko dostawa obiektów budownictwa mieszkaniowego lub ich części, z wyjątkiem obiektów i ich części, które mają być zasiedlone lub zamieszkane po raz pierwszy. Zwolnienie to nie dotyczyło części budynków przeznaczonych na cele inne niż mieszkalne. W konsekwencji można przyjąć, że praktycznie cała sprzedaż mająca za przedmiot budynki mieszkalne, a zatem i lokale mieszkalne dokonywana na rynku wtórnym korzystała ze zwolnienia.

Zmiana regulacji dotyczącej zwolnień nieruchomości z podatku od towarów i usług w polskim porządku prawnym, a w konsekwencji zmiana w zakresie pojmowania pojęcia pierwszego zasiedlenia, związana była z koniecznością dostosowania polskiego systemu prawnego do postanowień prawa unijnego, tj. Dyrektywy 112. Pismem referencyjnym numer 2006/2542 Komisja Europejska wskazała, iż polska regulacja dotycząca zwolnień (przed nowelizacją przepisów w tym zakresie) narusza prawo wspólnotowe. Zdaniem Komisji zgodnie z art. 135 ust. 1 lit. j Dyrektywy $112 \mathrm{w}$ powiązaniu z art. 12 ust. 1 lit. a tej dyrektywy: a) dostawy budynków lub ich części podlegają VAT, jeśli dokonane są odpłatnie przez podatnika, b) dostawa zwolniona jest z podatku VAT, jeśli ma miejsce po pierwszym zasiedleniu. Ponadto, zgodnie z art. 12 ust. 2 Dyrektywy 112 państwa członkowskie mogą określić szczegółowe zasady stosowania kryterium, o którym mowa w ust. 1 lit. a tego artykułu, do przebudowy budynków oraz zdefiniować pojęcie „gruntu związanego z budynkiem”. Państwa członkowskie uprawnione są również, na podstawie postanowień tego samego artykułu, do zastosowania kryteriów innych niż kryterium pierwszego zasiedlenia, takie jak okres upływający między datą ukończenia budynku a datą pierwszej dostawy lub też okres upływający między datą pierwszego zasiedlenia a datą następnej dostawy, pod warunkiem, że okresy te nie przekraczają odpowiednio pięciu i dwóch lat. Polska ustawa o podatku VAT w ówczesnym brzmieniu była niezgodna z przepisami Dyrektywy 112, gdyż do zwolnienia nieruchomości z podatku VAT konieczne było spełnienie łącznie dwóch warunków. Dostawa budynku musiała nastąpić po pierwszym zasiedleniu oraz budynek musiał być przeznaczony do celów mieszkalnych. 
Nowelizacja polskiej ustawy o VAT, która weszła w życie z początkiem roku 2009, nie tylko skutkowała poszerzeniem zakresu zwolnień o nieruchomości niebędące budynkami mieszkalnymi lub ich częściami (budynki, budowle lub ich części), ale również spowodowała zmodyfikowanie definicji pierwszego zasiedlenia nieruchomości. Ustawodawca w art. 2 ustawy o VAT, w brzmieniu po nowelizacji, określił, iż przez pierwsze zasiedlenie rozumie się oddanie do użytkowania, w wykonaniu czynności podlegających opodatkowaniu, pierwszemu nabywcy lub użytkownikowi budynków, budowli lub ich części, po ich: a) wybudowaniu, lub, b) ulepszeniu, jeżeli wydatki poniesione na ulepszenie, w rozumieniu przepisów o podatku dochodowym, stanowiły co najmniej 30\% wartości początkowej. Na rozumienie pojęcia zasiedlenia ma również wpływ fakt, że nowelizacją przestało ono dotyczyć wyłącznie budownictwa mieszkaniowego i obecnie obejmuje obecnie wszystkie budynki, budowle i ich części.

Zgodnie z brzmieniem polskiej ustawy o VAT pojęcia pierwszego zasiedlenia nie można rozumieć poprzez odwołanie się do języka potocznego $^{21}$. Definicja pierwszego zasiedlenia $\mathrm{z}$ ustawy składa się bowiem z dwóch współistniejących ze sobą, podstawowych elementów: pierwszego, jakim jest oddanie nieruchomości do użytkowania pierwszemu nabywcy lub użytkownikowi, oraz drugiego, tj. wymogu, aby oddanie nieruchomości do użytkowania nastąpiło w wyniku czynności podlegającej opodatkowaniu. Ustawa o VAT nie określa, jak należy rozumieć pojęcie oddania nieruchomości do użytkowania pierwszemu nabywcy bądź użytkownikowi. Mając na uwadze wcześniej poczynione ustalenia dotyczące korzystania w prawie podatkowym z definicji właściwych innym gałęziom prawa, rozważenia wymaga możliwość odwołania się w tym zakresie się do przepisów pr. bud. ${ }^{22}$ Regulacja dotycząca oddawania do użytkowania obiektu budowlanego zawarta jest w artykule 60 Ustawy prawo budowlane. Dotyczy ona jednak przekazania takiego obiektu wyłącznie właścicielowi lub zarządcy obiektu, a nie jego pierwszemu na-

\footnotetext{
21 A. Bartosiewicz, VAT Komentarz, wyd. 8, Warszawa 2014, s. 55, jak również A. Piątkowska-Chmiel, Komentarz do art. 43..., s. 425.

22 G. Kaptur, Zwolnienie dostawy..., s. 23-24.
} 
bywcy lub użytkownikowi. Ustalenia dotyczące oddania obiektu budowlanego do użytkowania nie mogą być zatem pomocą przy wyjaśnianiu warunków pierwszego zasiedlenia lokalu mieszkalnego na gruncie ustawy o VAT. Organy podatkowe, nie mogąc skorzystać z interpretacji terminu oddania do użytkowania wynikającej z uregulowań prawa budowlanego, kierują się potocznym rozumieniem tego pojęcia. Przykładowo w interpretacji indywidualnej z dnia 12 lutego 2010 r. Dyrektor Izby Skarbowej w Warszawie wskazał, iż oddanie do użytkowania należy rozumieć jako przekazanie budynków, budowli lub ich części ich nabywcy lub użytkownikowi do korzystania w sposób zgodny z zakresem przekazanych do nich praw $^{23}$. Dodatkowo $w$ interpretacji indywidualnej z dnia 23 grudnia 2009 r. Dyrektor Izby Skarbowej określa, że spełnienie przesłanki oddania nieruchomości do użytkowania nie musi być związane z faktycznym zamieszkaniem w nieruchomości ${ }^{24}$. Dla spełnienia tej przesłanki, zdaniem Dyrektora Izby Skarbowej, wystarczające jest przejęcie nieruchomości przez nabywcę do użytkowania. Jeszcze szerzej pojęcie oddania nieruchomości do użytkowania pierwszemu nabywcy lub użytkownikowi budynków definiuje Naczelny Sąd Administracyjny w orzeczeniu z dnia 30 października 2014 r. ${ }^{25}$ Zdaniem NSA pojęcie oddania do użytkowania z ustawy o VAT obejmuje każdą formę korzystania z budynków, budowli lub ich części.

O ile ustalenie intencji ustawodawcy podatkowego w zakresie określenia pojęcia pierwszego zasiedlenia na gruncie polskiej ustawy o VAT wydaje się nie budzić większych trudności, o tyle znaczące wątpliwości powstają w związku z uzależnieniem zaistnienia tego pojęcia od wykonania czynności podlegającej opodatkowaniu. W cytowanym już orzeczeniu z dnia 30 października 2014 r., powołując się na wątpliwości wyrażone

23 Interpretacja indywidualna Dyrektora Izby Skarbowej w Warszawie IPPP1-4431184/09-3/JB z dnia 12 lutego 2010 r., www.mofnet.gov.pl (dostęp: 20.06.2016 r.).

24 Interpretacja indywidualna Dyrektora Izby Skarbowej w Warszawie IPPP1/443-1054/093/AW z dnia 23 grudnia 2009 r., www.mofnet.gov.pl (dostęp: 20.06.2016 r.).

25 Wyrok NSA z dnia 30 października 2014 r., I FSK 1545/13, LEX nr 1552257, tak samo Wyrok NSA z dnia 9 czerwca 2015 r., I FSK 213/14, CBOSA. 
w literaturze ${ }^{26}$, NSA podkreśla, że powiązanie zwolnienia z podatku VAT z wykonaniem czynności opodatkowanej, a nie z rozpoczęciem użytkowania, nie znajduje uzasadnienia systemowego. Według NSA podatek VAT powinien być podatkiem obciążającym konsumpcję, a zatem powinien być neutralny wobec przedsiębiorców. Przepisy Dyrektywy 112 dają ustawodawcy krajowemu pewien zakres elastyczności w zakresie ukształtowania pojęcia pierwszego zasiedlenia. Zakres ten dotyczy jednak, jak wskazuje orzecznictwo Trybunału Sprawiedliwości Unii Europejskiej ${ }^{27}$, określonej kategorii czynności, jaką jest przebudowa budynku, i wynika bezpośrednio z trudności związanych z określeniem momentu pierwszego zasiedlenia nieruchomości w związku z jej przebudową. W swoim orzecznictwie Trybunał Sprawiedliwości UE podkreśla, iż nie ma wątpliwości, że pierwsze zasiedlenie ma miejsce w sytuacji, gdy podatnik wybudował nieruchomość, a następnie wykorzystywał ją na potrzeby prowadzonej przez siebie działalności gospodarczej ${ }^{28}$. Ponadto, jak zauważył rzecznik generalny w swojej opinii w sprawie Blasi ${ }^{29}$, podjęcie działań związanych z gruntem rozpoczyna etap zwiększania wartości ekonomicznej tego gruntu, którego zwieńczeniem jest dostawa nieruchomości. W ocenie rzecznika, brak jest uzasadnienia dla opodatkowania nieruchomości podatkiem VAT, gdy proces ten został zakończony. Korzystanie z nieruchomości w późniejszym czasie, w tym w szczególności jej późniejsza dostawa, nie skutkują powstaniem jakiejkolwiek wartości dodanej. Tego rodzaju ustalenia stanowiły podstawę do wydania w dniu 14 maja 2015 r. ${ }^{30}$ przez Naczelny Sąd Administracyjny wyroku, w którym Sąd stwierdził częściową niezgodność art. 2 pkt. 14 lit. a ustawy o VAT z art. 12 ust. 1 lit. a i 2 Dyrektywy 112, jak też art. 135 ust. 1

26 Więcej: S. Majerowski, D. Pokrop, Komentarz do art. 131-137 Dyrektywy 2006/112/WE, [w:] Dyrektywa VAT. Polska perspektywa. Komentarz, R. Namysłowski (red.), Warszawa 2012, s. 221-286 oraz A. Bartosiewicz, VAT. Komentarz..., s. 55. Wyrok ETS z dnia 12 lipca 2012 r. w sprawie C-326/11 J.J. Komen en Zonen Beheer Heerhugowaard BV v. Staatssecretaris van Financiën, ECLI:EU:C:2012:461.

28 Wyrok ETS z dnia 25 lutego 2013 r. w sprawie C-92/13 Gemeente's-Hertogenbosch v. Staatssecretaris van Financiën, EU:C:2014:2188.

29 Opinia rzecznika generalnego F.G. Jacobs z dnia 25 września 1997 r. w sprawie Case C-346/95 Elisabeth Blasi v. Finanzamt München I, ECLI:EU:C:1997:432.

30 Wyrok NSA z dnia 14 maja 2015 r. I FSK 382/14, CBOSA. 
lit. j tej Dyrektywy, w zakresie, w jakim polska ustawa o VAT uzależnia pierwsze zasiedlenie nieruchomości od zaistnienia czynności podlegającej opodatkowaniu. W ocenie NSA definicja pierwszego zasiedlenia zawarta w Dyrektywie 112 ma charakter autonomiczny i nie istniała potrzeba ponownego definiowania tego pojęcia na gruncie ustawodawstwa polskiego, poza przypadkami dotyczącymi przebudowy nieruchomości ${ }^{31}$. Definicja przyjęta w polskiej ustawie o VAT ogranicza zakres pojęcia pierwszego zasiedlenia wynikający z Dyrektywy 112. Kierując się zasadami wykładni prounijnej, NSA w komentowanym orzeczeniu stwierdził, że poprzez pierwsze zasiedlenie, o którym mowa w art. 2 pkt. 14 lit. a ustawy o VAT, należy rozumieć użytkowanie przez pierwszego nabywcę lub użytkownika budynków, budowli lub ich części, po ich wybudowaniu. Wątpliwości dotyczące rozumienia pojęcia pierwszego zasiedlenia skutkowały skierowaniem przez NSA postanowieniem z dnia 23 lutego 2016 r. ${ }^{32}$ pytania prejudycjalnego do Trybunału Sprawiedliwości Unii Europejskiej w przedmiocie prawidłowości implementacji przepisów Dyrektywy 112 dotyczących zasiedlenia do polskiej ustawy o VAT. Naczelny Sąd Administracyjny wystąpił do Trybunału z następującym pytaniem: czy art. 135 ust. 1 lit. j) Dyrektywy 112 w sprawie wspólnego systemu podatku od wartości dodanej należy interpretować w ten sposób, że sprzeciwia się krajowemu uregulowaniu (art. 43 ust. 1 pkt. 10 ustawy o VAT), zgodnie z którym zwolniona od VAT jest dostawa budynków, budowli lub ich części, z wyjątkiem, gdy a) dostawa jest dokonywana w ramach pierwszego zasiedlenie lub przed nim, b) pomiędzy pierwszym zasiedleniem a dostawą budynku, budowli lub ich części upłynął okres krótszy niż 2 lata w zakresie, w jakim art. 2 pkt. 14 ustawy o VAT definiuje, że pierwszym zasiedleniem jest oddanie do użytkowania budynków, budowli lub ich części, po ich a) wybudowaniu lub b) ulepszeniu, jeżeli wydatki poniesione na ulepszenie, w rozumieniu przepisów o podatku dochodowym, stanowiły co najmniej 30\% wartości początkowej.

31 Szerzej: Wyrok ETS z dnia 4 czerwca 2009 r. w sprawie C-102/08 ALIX Finanzamt Düsseldorf-Süd v. SALIX Grundstücks - Vermietungsgesellschaft GmbH \& C. Objekt Offenbach KG, ECR I-4629.

Postanowienie NSA z dnia 23 lutego 2016 r., I FSK 1573/14, CBOSA. 
Innymi słowy, NSA zwrócił się do TSUE o wyjaśnienie, czy pierwszemu zasiedleniu, jak to wynika z polskiej ustawy o VAT, musi towarzyszyć czynność podlegająca opodatkowaniu, czy też pierwsze zasiedlenie nieruchomości należy rozumieć, jako faktyczne zasiedlenie budynku, tj. oddanie go do faktycznego użytkowania po wybudowaniu lub przebudowie/renowacji, jeżeli wskutek przebudowy/renowacji powstała przekształcona nieruchomość.

Rozstrzygnięcia w sprawie zadanego przez Naczelny Sąd Administracyjny pytania prejudycjalnego dotyczącego prawidłowości dokonania transpozycji do polskiego porządku prawnego przepisów Dyrektywy 112 w zakresie zasiedlenia, a zatem w zakresie rozumienia pojęcia pierwszego zasiedlenia, należy spodziewać się nie wcześniej niż w 2017 r. Do tego czasu po stronie zarówno podatników, organów podatkowych, jak i sądów pozostaną wątpliwości co do oceny, czy w konkretnych przypadkach doszło już do pierwszego zasiedlenia nieruchomości. W konsekwencji deweloper w ramach działalności swojej spółki celowej, będzie miał trudności w ocenie, jakie kroki podjąć w celu opodatkowania transakcji sprzedaży lokalu mieszkalnego podatkiem VAT. Wydaje się, że w obecnym stanie faktycznym najbezpieczniejszym dla dewelopera będzie składanie wraz z nabywcą oświadczenia o wyborze opodatkowania podatkiem VAT w każdej sytuacji, gdy pojawią się wątpliwości co do upływu okresu dwóch lat od pierwszego zasiedlenia na podstawie art. 43 ust. 1 pkt. 10 ustawy o VAT. Niewątpliwie jednak trzeba mieć również na uwadze zbadanie, czy w danym przypadku zwolnienie nie będzie zwolnieniem obligatoryjnym z art. 43 ust. 1 pkt. 10 a tej samej ustawy.

\section{Wybór opcji opodatkowania}

W przypadku ustalenia, że dostawa lokalu mieszkalnego spełnia przesłanki do jej zwolnienia z opodatkowania podatkiem VAT z art. 43 ust. 1 pkt. 10 ustawy o VAT (lub w przypadku zaistnienia wątpliwości co do możliwości spełnienia tych przesłanek), przy jednoczesnym braku spełnienia przesłanek z pkt. 10a tego samego artykułu, podatnikowi przysługuje możliwość wyboru opcji opodatkowania. Opodatkowanie dostawy 
budynku, budowli lub ich części podatkiem VAT na podstawie postanowień art. 43 ust. 10 ustawy o VAT jest fakultatywne, tj. w przypadku niepodjęcia przez podatnika określonych aktywności i przy braku spełnienia określonych przesłanek, niezależnie od woli podmiotu, transakcja korzystać będzie ze zwolnienia z podatku od towarów i usług. Z punktu widzenia dewelopera, sam fakt wprowadzenia do polskich przepisów prawa podatkowego instytucji rezygnacji ze zwolnienia z podatku VAT należy określić jako pozytywny. Deweloper, organizując prowadzoną przez siebie działalność gospodarczą, uzyskuje dodatkowe narzędzie umożliwiające uelastycznienie tej działalność. Dokonując bowiem sprzedaży lokali mieszkalnych pomiędzy swoimi spółkami, czy to w celach optymalizacji podatkowej, czy też w celu uniknięcia konieczności zastosowania przepisów ustawy deweloperskiej, ma świadomość możliwości skorzystania przy kolejnych dostawach z formy opodatkowania nieruchomości podatkiem VAT (co nie będzie mieć wpływu na ustaloną cenę sprzedaży) z pominięciem opodatkowania lokalu podatkiem od czynności cywilnoprawnych (co może skutkować podniesieniem kosztów zakupu przez ostatniego nabywcę). Niestety, na co zwraca się uwagę w literaturze, możliwość skorzystania z opodatkowania dostawy podatkiem VAT obarczona została przez polskiego ustawodawcę szeregiem wymogów, których spełnienie wydaje się nie mieć uzasadnienia zarówno w przepisach Dyrektywy 112, jak i w orzecznictwie Trybunału Sprawiedliwości UE ${ }^{33}$.

Na podstawie przepisu art. 43 ust. 10 ustawy o VAT podatnik może dokonać rezygnacji ze zwolnienia z podatku VAT po spełnieniu dwóch przesłanek o charakterze kumulatywnym. Spełnienie tych przesłanek wymaga wspólnej aktywności i podmiotu dokonującego dostawy (w tym przypadku dewelopera) i nabywcy nieruchomości. Po pierwsze, oba podmioty muszą być zarejestrowane jako podatnicy VAT czynni. Po drugie, oba podmioty przed dokonaniem dostawy muszą złożyć, właściwemu dla nabywcy naczelnikowi urzędu skarbowego, zgodne oświadczenie, że wybierają opodatkowanie dostawy budynku, budowli lub ich

33 E. Bobrus, Opodatkowanie przeniesienia..., s. 245. 
części. Analizując pierwszą ze wskazanych przesłanek, należy uznać, że rezygnacja ze zwolnienia z opodatkowania podatkiem VAT będzie mogła nastąpić wyłącznie pomiędzy podmiotami będącymi czynnymi podatnikami podatku VAT, z wyłączeniem osób fizycznych nieprowadzących działalności gospodarczej, względnie niezarejestrowanych jako podatnicy VAT czynni. Jeżeli zatem spółce celowej nie uda się sprzedać lokalu mieszkalnego w okresie dwóch lat od pierwszego zasiedlenia (z zastrzeżeniem wątpliwości co do rozumienia tego pojęcia), to każda sprzedaż na rzecz osoby fizycznej niezarejestrowanej jako podatnik VAT czynny będzie opodatkowana podatkiem od czynności cywilnoprawnych. Pomimo, że transakcja nie będzie opodatkowana podatkiem VAT, spółka celowa nie obniży ceny sprzedaży, gdyż pozbawiona zostaje możliwości odliczenia podatku naliczonego (często brak możliwości obniżenia ceny wynikać będzie również z postanowień umowy kredytowej łączącej spółkę celową z bankiem kredytującym). Osoba fizyczna zapłaci zatem w cenie sprzedaży nie 8\% podatku (stawka właściwa dla lokali mieszkalnych do $150 \mathrm{~m}^{2}$ powierzchni) lecz 10\% (cena netto „powiększona o podatek VAT” powiększona o 2\% podatku od czynności cywilnoprawnych). Jeżeli nawet spółka celowa dewelopera zdecyduje się na obniżenie ceny, to takie działanie skutkować będzie pogorszeniem wyniku finansowego tej spółki. Wydaje się, że deweloperzy nie są w stanie na przestrzeni kilku lat (zakup gruntu, budowa, sprzedaż) zaplanować, jaka część lokali nie zostanie zbyta w okresie 2 lat od pierwszego zasiedlenia, zatem będą mieć problemy w wkalkulowaniem tego ryzyka podatkowego w koszty prowadzonej przez siebie działalności gospodarczej. W celu skorzystania z możliwości opodatkowania dostawy lokalu mieszkalnego podatkiem VAT deweloperzy zachęcają osoby fizyczne (nabywców) do nabywania lokalu mieszkalnego na potrzeby prowadzonej działalności gospodarczej bądź bezpośrednio do majątku spółek powiązanych z osobą fizyczną nabywcą, bądź też do zakładania działalności gospodarczych, a najczęściej do rejestrowania się przez osoby fizyczne jako czynni podatnicy podatku VAT, bez zakładania takiej działalności. Niewątpliwie zatem ukształtowanie regulacji podatkowej w zakresie możliwości rezygnacji ze zwolnienia z opodatkowania podatkiem VAT oddziałuje na ukształtowa- 
nie rynku nieruchomości, poprzez zmiany w zakresie katalogu nabywców. W celu skorzystania z instytucji rezygnacji ze zwolnienia z opodatkowania podatkiem VAT sam fakt rejestracji strony jako czynnego podatnika podatkiem VAT powinien nastąpić przed dokonaniem dostawy nieruchomości. W praktyce notarialnej ${ }^{34}$ przyjmuje się różnie, iż potwierdzeniem rejestracji podmiotu jako podatnika VAT czynnego powinno być zaświadczenie potwierdzające status podatnika VAT czynnego, względnie potwierdzenie nadania numeru NIP wraz z deklaracją za ostatni okres rozliczeniowy, bądź wreszcie samo oświadczenie podmiotu o fakcie bycie czynnym podatnikiem VAT złożone w treści aktu notarialnego.

Druga z przesłanek, a więc konieczność złożenia oświadczenia o wyborze opodatkowania, wydaje się budzić jeszcze większe wątpliwości pod kątem nadmiernego formalizmu. Artykuł 43 ust. 10 ustawy o VAT wyraźnie wskazuje, że oświadczenie o wyborze opodatkowania powinno być złożone przed dniem dokonania dostawy, do naczelnika US właściwego ze względu na osobę nabywcy i powinno zawierać następujące element (art. 43 ust. 11 tej Ustawy): imiona i nazwiska lub nazwę, adresy oraz numery identyfikacji podatkowej dokonującego dostawy i nabywcy, planowaną datę zawarcia umowy dostawy, adres budynku, budowli lub ich części. W wyroku z dnia 20 stycznia 2016 r. WSA w Szczecinie ${ }^{35}$ wskazał, że termin na złożenie oświadczenia o wyborze opodatkowania jest terminem materialnoprawnym, gdyż określa warunki uprawniające podatnika do możliwości zrezygnowania ze zwolnienia i opodatkowania dostawy, zatem wpływa on na prawa i obowiązki podatnika. Zdaniem sądu termin ten nie podlega przywróceniu, a jego uchylenie powoduje wygaśnięcie uprawnienia. Brzmienie przepisu art. 43 ust. 10 pkt. 2 nie pozostawia żadnego marginesu interpretacji w zakresie terminu złożenia oświadczenia o wyborze opodatkowania. Trudno jednak zrozumieć i zaakceptować treść tej regulacji. Mając na uwadze bezpie-

34 Zgodnie z art. 10 ust. 2 ustawy z dnia 9 września 2000 r. o podatku od czynności cywilnoprawnych (tekst jedn. Dz.U. z 2016, poz. 223 ze zm.) notariusze są płatnikami podatku od czynności cywilnoprawnych dokonanych w formie aktu notarialnego, a zbycie lokalu wymaga formy aktu notarialnego.

35 Wyrok WSA w Szczecinie z dnia 20 stycznia 2016 r., I SA/Sz 1251/15, niepubl. LEX nr 1995979. 
czeństwo obrotu prawnego, przede wszystkim na konieczność współdziałania obu stron transakcji w zakresie decyzji o wyborze opodatkowania, nie wydaje się, aby racjonalne było umożliwienie podatnikom składania takiego oświadczenia po dokonaniu dostawy, rozumianej jako zawarcie umowy sprzedaży ${ }^{36}$. Z punktu widzenia podatkowo-prawnego nie ma jednak przeszkód, aby oświadczenie o wyborze opodatkowania składane były w treści umowy sprzedaży - aktu notarialnego, przed notariuszem. Nie wydaje się, aby istniała konieczność wcześniejszego zawiadamiania organu podatkowego o zamiarze dokonania dostawy nieruchomości, a wymagana dla zbycia nieruchomości forma aktu notarialnego stanowi swoistą gwarancję transparentności dokonywanego obrotu. Wątpliwości budzi również konieczność składania zgodnego oświadczenia o wyborze opodatkowania do US właściwego dla nabywcy. Przepis nie wskazuje, czy oświadczenie powinno być złożone na jednym dokumencie, określa jedynie, że powinno być ono zgodne. W przypadku gdy zbywca i nabywca przebywają na tym samym obszarze kraju obowiązek złożenia oświadczenia, nawet na jednym dokumencie nie powinien powodować zbyt dużych trudności. Problematyczne staje się złożenia oświadczenia, gdy obie strony transakcji przebywają w różnych regionach Polski, bądź nabywca jest obcokrajowcem, a zamiarem stron było spotkanie się wyłącznie $\mathrm{w}$ momencie dokonywania transakcji zbycia, a nie na dzień przed tą transakcją. Przepis art. 43 ust. 10 ustawy o VAT nie precyzuje, w jakiej formie powinno zostać złożone oświadczenie o wyborze opodatkowania. W ocenie $\mathrm{NSA}^{37}$ nie oznacza to jednak, że oświadczenie takie może być składane w formie dowolnej, lecz iż należy w tym względzie posłużyć się przepisami ogólnego prawa podatkowego. Zdaniem NSA, choć art. 168 Ordynacji Podatkowej ${ }^{38}$ nie posługuje się pojęciem oświadczenia, to „brak jest przeszkód do objęcia tym przepisem natury ogólnej również oświadczenia, o którym mowa w art. 43 ust. 10 pkt. 2 ustawy o VAT”. Jak wskazuje się w literaturze, w definicji podania z art. 168 Ordynacji

\footnotetext{
Definicja „dostawy” z art. 7 ustawy o VAT.

Wyrok NSA z dnia 10 kwietnia 2014 r., I FSK 668/13, LEX nr 1484718.

Ustawa z dnia 29 sierpnia 1997 r. Ordynacja Podatkowa (tekst. jedn. Dz.U. z 2015 r., poz. 613 , ze zm.).
} 
mieszczą się w zasadzie wszystkie czynności procesowe oraz pozaprocesowe wszystkich uczestników postępowania podatkowego, z którymi występują oni wobec organu podatkowego ${ }^{39}$. Oświadczenie zatem, tak jak podanie, może zostać wniesione pisemnie lub ustnie do protokołu, a także za pomocą środków komunikacji elektronicznej przez elektroniczną skrzynkę podawczą organu podatkowego (utworzoną zgodnie z obowiązującymi przepisami) lub przez portal podatkowy. W konsekwencji, nawet jeśli dana dostawa nieruchomości spełnia przesłanki do wyboru jej opodatkowania podatkiem VAT, to w przypadku złożenia oświadczenia po terminie, bądź w nieodpowiedniej formie (tj. np. jak wskazuje NSA w swoim orzeczeniu urzędnikowi w formie telefonicznej), transakcja nie będzie mogła być opodatkowana podatkiem VAT.

Warto również zwrócić uwagę na elementy obligatoryjne, które zawierać musi oświadczenia o wyborze opodatkowania. O ile racjonalne wydaje się umieszczanie w oświadczeniu danych dotyczących stron umowy dostawy, ich danych adresowanych, jak również danych nieruchomości podlegającej zbyciu, o tyle trudne dla stron transakcji może być precyzyjne określenie terminu zawarcia umowy sprzedaży. Termin przeniesienia prawa własności zależny może być bowiem od uzyskania pozytywnej decyzji kredytowej i podpisania umowy kredytowej przez nabywcę, a nawet od tego, czy przelew bankowy (środki tytułem zapłaty ceny sprzedaży) dotrze w odpowiednim dniu na rachunek sprzedającego, czy też rachunek depozytowy notariusza. Wydaje się, że najbezpieczniejszym dla stron transakcji będzie składanie oświadczenia ze wskazaniem pewnego przedziału czasowego, w którym dojść ma do przeniesienia prawa własności, z ewentualną adnotacją, iż w tym okresie strony nie złożą naczelnikowi US oświadczenia o odmiennej treści.

39 P. Pietrasz, Komentarz do art. 168 Ordynacji Podatkowej, [w:] J. Brolik, R. Dowgier, L. Etel, C. Kosikowski, P. Pietrasz, M. Popławski, S. Presnarowicz, W. Stachurski, Ordynacja Podatkowa. Komentarz, Warszawa, 2013. s. 959. 


\section{Podsumowanie}

Przeprowadzone rozważania wskazują, iż regulacja w zakresie rezygnacji ze zwolnienia dostawy lokalu mieszkalnego z podatku VAT charakteryzuje się nadmiernym poziomem formalizmu, co nie wydaje się być uzasadnione celami opodatkowania. Poziom skomplikowania i wymogi techniczne związane $\mathrm{z}$ możliwością rezygnacji ze zwolnienia $\mathrm{z}$ opodatkowania podatkiem VAT (w szczególności dotyczące formy i terminu złożenia oświadczenia dotyczącego rezygnacji) nie przyczyniają się do uelastyczniania obrotu, wydają się natomiast ten obrót hamować. Decyzja w zakresie zakupu lokalu mieszkalnego od dewelopera może być bowiem podejmowana w sposób przemyślany, jednak często jest to decyzja o charakterze ad hoc, chociażby ze względu na możliwość uzyskania chwilowej, korzystnej oferty. Istotnym wydaje się postulat, aby ograniczyć wymogi formalne związane $\mathrm{z}$ wyborem opodatkowania poprzez umożliwienie składania stronom transakcji oświadczenia o rezygnacji ze zwolnienia z opodatkowania dostawy podatkiem VAT w treści aktu notarialnego - umowy sprzedaży.

Trudności w zastosowaniu przepisu art. 43 ust. 10 i 11 ustawy o VAT wynikają nie tylko z poziomu skomplikowania regulacji dotyczącej zwolnień, ale również z budzącego wątpliwości sposobu transpozycji do polskiego porządku prawnego Dyrektywy 112. Słuszne są obawy Naczelnego Sądu Administracyjnego co do tego, czy polskie prawo może ograniczać pojęcie pierwszego zasiedlenia, warunkując jego zastosowanie zaistnieniem czynności podlegającej opodatkowaniu. Wydaje się, że do momentu wydania rozstrzygnięcia przez Trybunał Sprawiedliwości Unii Europejskiej w przedmiocie zgodności polskiej regulacji z prawem unijnym będziemy mieć do czynienia z chaosem prawno-podatkowym dotyczącym regulacji dotyczącej zwolnień dostawy budynków, budowli lub ich części, a w konsekwencji w zakresie możliwości skorzystania przez strony umowy sprzedaży z rezygnacji z takiego zwolnienia. 


\section{Bibliografia:}

Bańko M. (red.), Słownik języka polskiego, Tom I, Wydawnictwo Naukowe PWN SA, Warszawa 2007.

Bartosiewicz A., VAT Komentarz, wyd. 8, Wydawnictwo Lexis Nexis, Warszawa 2014.

Bobrus E., Opodatkowanie przeniesienia własności nieruchomości, Oficyna a Wolters Kluwer business, Warszawa 2012.

Borszowski P., Działalność gospodarcza w konstrukcji prawnej podatku, Oficyna a Wolters Kluwer business, Warszawa 2010.

Brolik J., Dowgier R., Etel L., Kosikowski C., Pietrasz P., Popławski M., Presnarowicz S., Stachurski W., Ordynacja Podatkowa. Komentarz, Oficyna a Wolters Kluwer business, Warszawa 2013.

Kopyściańska K., Przeglq̨d bieżq̨cych problemów zwiq̨zanych z opodatkowaniem nieruchomości na tle orzecznictwa sq̨dów administracyjnych, Wydawnictwo Wydziału Prawa Administracji i Ekonomii Uniwersytetu Wrocławskiego, Wrocław 2015.

Kaptur G., Zwolnienie dostawy budynków/budowli w podatku VAT, cz. I, „Nieruchomości” 2011, nr 8, s. 20-26.

Kosikowski C., Ruśkowski E., Borodo A., Finanse publiczne i prawo finansowe, Oficyna a Wolters Kluwer business, Warszawa 2008.

Koziollek J., Najem komercyjny lokali mieszkalnych a zwolnienie z podatku VAT, „Studenckie Prace Prawnicze, Administratywistyczne i Ekonomiczne” 2015, nr 17, s. 99-113.

Matarewicz J. (red.), Ustawa o podatku od towarów i usług. Komentarz, Wydawnictwo Prawnicze Lexis Nexis, Warszawa 2013.

Namysłowski R., Dyrektywa VAT. Polska perspektywa. Komentarz, Oficyna a Wolters Kluwer business, Warszawa 2012.

Nykiel W., Wykładnia prawa podatkowego wewnętrznego, międzynarodowego, i prawa podatkowego Unii Europejskiej (wybrane zagadnienia), „Kwartalnik Prawa Podatkowego” 2004, nr 4, s. 127-137.

Wolański R., System podatkowy w Polsce, Wydawnictwo Wolters Kluwer SA, Warszawa 2016. 